\title{
Microstructure of the Triassic conodont Pseudofurnishius murcianus van den Boogaard: Functional implications
}

\section{Carlos MARTINEZ-PÉREZ ${ }^{*}$, Pablo PLASENCIA ${ }^{2}$ \& Ana MÁRQUEZ-ALIAGA ${ }^{2}$}

\author{
${ }^{1}$ School of Earth Sciences, University of Bristol, Wills Memorial Building, Queen's Road, Bristol BS8 1RJ, UK.; Carlos. \\ Martinez-Perez@bristol.ac.uk \\ ${ }^{2}$ Instituto Cavanilles de Biodiversidad y Biologia Evolutiva y Departmento de Geology, Universidad de Valencia, Dr. Moliner, \\ 50 Burjassot, 46100 Valencia, Spain; Pablo.Plasencia@uv.es; Ana.Marquez@uv.es
}

* Corresponding author

Martínez-Pérez, C., Plasencia, P. \& Márquez-Aliaga, A. 2015. Microstructure of the Triassic conodont Pseudofurnishius murcianus van den Boogaard: Functional implications. [Microestructura del conodonto triásico Pseudofurnishius murcianus van den Boogaard: Implicaciones funcionales]. Spanish Journal of Palaeontology, 30 (1), 109-116.

\begin{abstract}
Pseudofurnishius murcianus van den Boogaard is a Triassic conodont with a very characteristic morphology, a blade with a rostral platform heavily denticulated, that makes it easily distinguishable from other coeval species. It is a well-know taxon that has been the object of several palaeobiological works, focused on their apparatus reconstruction, ontogeny and, recently, their $\mathrm{P}_{1}$ element function. In order to increase our palaeobiology knowledge of this taxon we undertook a histological analysis to corroborate the functional hypothesis established for this conodont. The histological study demonstrates the presence of different microstructural types, suggesting that they are functional adaptations due to the slicing function that the $\mathrm{P}_{1}$ elements performed.
\end{abstract}

Keywords: Microstructure, conodont function, palaeobiology.

\section{RESUMEN}

Pseudofurnishius murcianus van den Boogaard es un conodonto Triásico con una morfología muy característica, una lamina con una plataforma rostral fuertemente denticulada, que lo hace fácilmente distinguible de otras especies coetáneas. Se trata de un taxón bien conocido, que ha sido objeto de varios trabajos paleobiológicos centrados en la reconstrucción de su aparato, ontogenia y, recientemente, en la función del elemento $\mathrm{P}_{1}$. Con el fin de aumentar el conocimiento paleobiológico de este taxón, hemos realizamos un análisis histológico para corroborar las hipótesis funcionales establecidas para este conodonto. El estudio histológico demuestra la presencia de diferentes tipos microestructurales, que sugieren ser adaptaciones funcionales debido a la función de corte que realizarían los elementos $\mathrm{P}_{1}$.

Palabras clave: Microestructura, función conodontal, paleobiología. 


\section{INTRODUCTION}

Conodonts are an extinct group of animals that have been promoted as the earliest members of our evolutionary lineage to possess a mineralised skeleton (Donoghue et al., 2000). This skeleton is composed of an array of 'elements' that comprise a complex feeding apparatus, which function is still the centre of a hot debate, with two different and opposed views: conodont elements as filter supports (Nicoll, 1987; Blieck et al., 2010; Turner et al., 2010), or performing an efficient tooth-like function (Purnell, 1994, 1995; Donoghue \& Purnell, 1999a, b; Jones et al., 2012; Murdock et al., 2013a; Martínez-Pérez et al., 2014a, b). As such, the conodont skeleton is of great significance because of the insights it provides into the biology and function of the skeleton of the most primitive vertebrates. A recent work by Murdock et al. (2013b) has shown that the hard tissues of the euconodont elements are not homologous to the canonical vertebrate tissues dentine and enamel, showing that these tissues have evolved independently, being an extraordinary example of convergent evolution, not only at histological but also at functional level.

Enamel normally forms a thin layer that typically covers the outer surface of vertebrate teeth, the principal function of which is to retain the shape and resist fracture during loads (Rensberger, 1997). The hard enamel is among the most resistant of all skeletal biomaterials providing protection to the soft dentine interior. However, it is also one of the most brittle (Clemens, 1997). This mechanical limitation is particularly problematic in conodonts, since in the majority of species effectively the whole crown is composed of an analogous hypermineralised tissue (Donoghue \& Aldridge, 2001). In order to solve this mechanical disadvantage, tooth enamel of many vertebrates has evolved complex microstructures with variations in the inner arrangements of the crystallites, reducing the homogeneity of the tissue and increasing its resistance to crack propagation (Rensberger, 1997). Hence, this microstructural differentiation has been traditionally linked to adaptations to dental function (Rensberger \& Koenigswald, 1980; Rensberger, 1992, 1993, 1997; Clemens, 1997).

If conodont elements functioned as teeth (Purnell, 1995), it would be very surprising if their crown tissue microstructure showed no evidence of adaptation to increased resistance to stress. In fact, conodont crown tissue exhibits a great degree of microstructural variation (Donoghue, 1998, 2001), similar to that described in other groups of vertebrates, such as chondrichthyans (Gillis \& Donoghue, 2007); reptiles (Heckert et al., 2013), or mammals (Koenigswald, 1988; Rensberger 1992), among others, reflecting an extraordinary example of functional convergence (Donoghue, 2001; Martínez-Pérez et al., 2014a).

In this context, the aim of this work is to study of inner microstructure of the $\mathrm{P}_{1}$ elements of the Triassic conodont Pseudofurnishius murcianus van den Boogaard
1966, in order to establish its functional significance. Our knowledge of its paleobiology has been increasing since Ramovs $(1977,1978)$ described very well preserved clusters that provided the base for the reconstruction of their apparatus. Plasencia et al. (2007) and Plasencia (2009), based on a large collection from Spain (where $P$. murcianus is commonly the only species in many sections), proposed improvements in this apparatus reconstruction. The morphological variability of $P$. murcianus has also been studied in detail by Bandel \& Waksmunzki (1985), Plasencia (2009) and Plasencia et al. (in press), and the ontogenetic development model has been described by Plasencia et al. (2010). More recently its occlusal cycle, based in the study of several clusters from Slovenia, has been described in detail (Martínez-Pérez et al., 2014b).

Thus, this work would represent an important contribution to the knowledge of $P$. murcianus, providing new information about the biology and function of this unusual blade-like conodont that has become in one of the best-known Triassic conodonts, and thus serve as a reference for future paleobiological studies of related conodont species.

\section{MATERIAL AND METHODS}

The present work is based on $\mathrm{P}_{1}$ elements of $P$. murcianus obtained after acid dissolution (acetic acid at $8 \%$ ) from several samples of the Henarejos and Bugarra sections. Both sections have been described within the Iberian Range, which extends in NW-SE direction from the central part of the Iberian Peninsula to the Mediterranean Sea, and correspond to materials from the upper Muschelkalk or $\mathrm{M}_{3}$, the second and more important marine transgression of the Middle Triassic, Ladinian in age (López-Gómez et al., 1998). A summary of the geology of both sections can be revised in Plasencia (2009). Pseudofurnishius murcianus is a well-known Ladinian (Middle Triassic) conodont species that characterized the Sephardic Province, but also present in the southern margins of Gondwana (Plasencia et al., 2007, in press; Ishida \& Hirsch, 2011). This taxon shows a morphology that makes it easily distinguishable from coeval species, with a laterally compressed blade $\mathrm{P}_{1}$ element that develops a reduced rostral platform composed by several denticles with a wide morphological variability, especially in the most developed specimens. In contrast, the caudal side is usually smooth (Fig. 1b), but isolated denticles can be found (Fig. 1c), and in some specimens these caudal denticles can form a ridge that in the most developed specimens forms a platform that can overgrow the rostral one (Fig. 1d).

This particular and uncommon morphology has been demonstrated controversial in order to establish the real anatomical orientation of the $\mathrm{P}_{1}$ elements in the animal. 
a

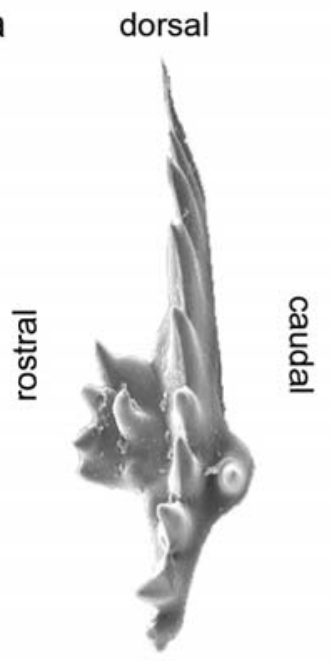

ventral b
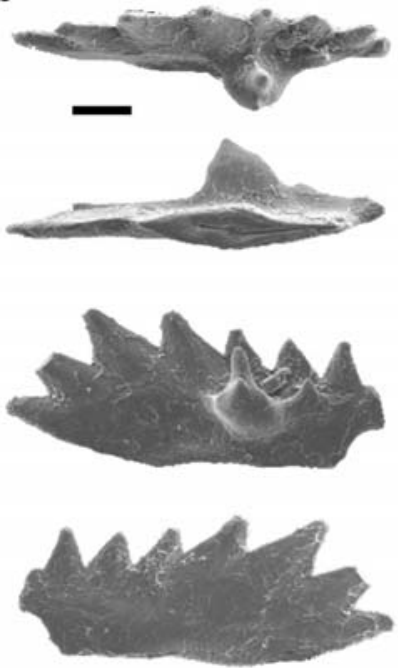
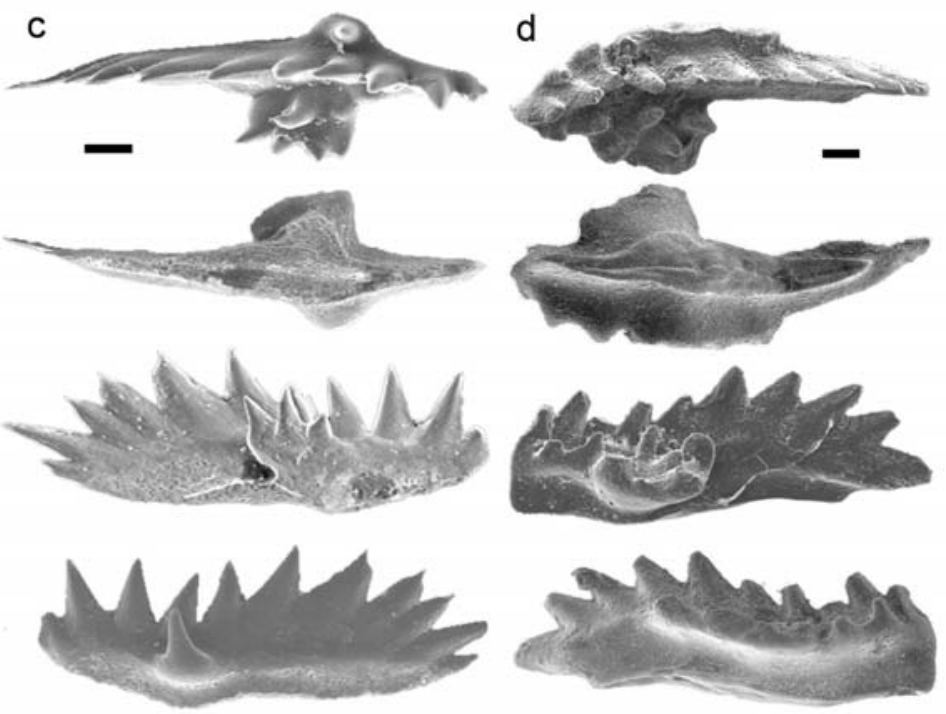

Figure 1. Morphology and variability within the species Pseudofurnishius murcianus van den Boogaard, 1966, modified from Plasencia (2009). a) Right element with the different anatomical terms, MGUV-10.480, Sample Cld-2703, Calanda section, Iberian Range, Ladinian. b) Right element, MGUV-19.993, Sample Li-8, Libros section, Iberian Range, Ladinian. c) Right element, MGUV-10.480, Sample Cld-2703, Calanda section, Iberian Range, Ladinian. d) Left element, MGUV-10.035, sample He20, Henarejos section, Iberian Range, Ladinian. Scale bars $50 \mu \mathrm{m}$.

However, this problem has been recently solved by the analysis of the ontogenetical development of the $\mathrm{P}_{1}$ elements (Plasencia et al., 2010), and the study of several cluster representing the real (in vivo) position (MartínezPérez et al., 2014b). These previous works have definitively established its real anatomical position within the conodont apparatus allowing us a correct description and comparison with other pectiniform conodonts (see Fig. 1a, and Fig. 2 for anatomical terms).

For the histological study, more than $20 \mathrm{P}_{1}$ elements were embedded in transparent polyester resin and cut in transversal, sagittal or longitudinal section (Fig. 2) using a diamond blade on a low speed saw. These surfaces were ground with carborundum powder (800 and $1200 \mu \mathrm{m})$ until the desired plane of section was reached. Finally, the samples were etched using $0.5 \%$ orthophosphoric acid for 5 to 10 minutes. The elements were photographed with a scanning electron microscope (SEM) Hitachi S-4100 hosted at the University of Valencia. The samples were polished, etched, and coated as many times as was necessary to study the inner microstructure. We have also studied the microstructure of artificial fractures produced with an entomological needle mounted in a pin vice and applying a force in the middle parts of the free blade. As with the included elements, they were etched using $0.5 \%$ orthophosphoric acid (always for less than 10 minutes), and photographed with the SEM.

Specimens figured in the present work are housed in the Museu de Geologia de la Universitat de València (MGUV).

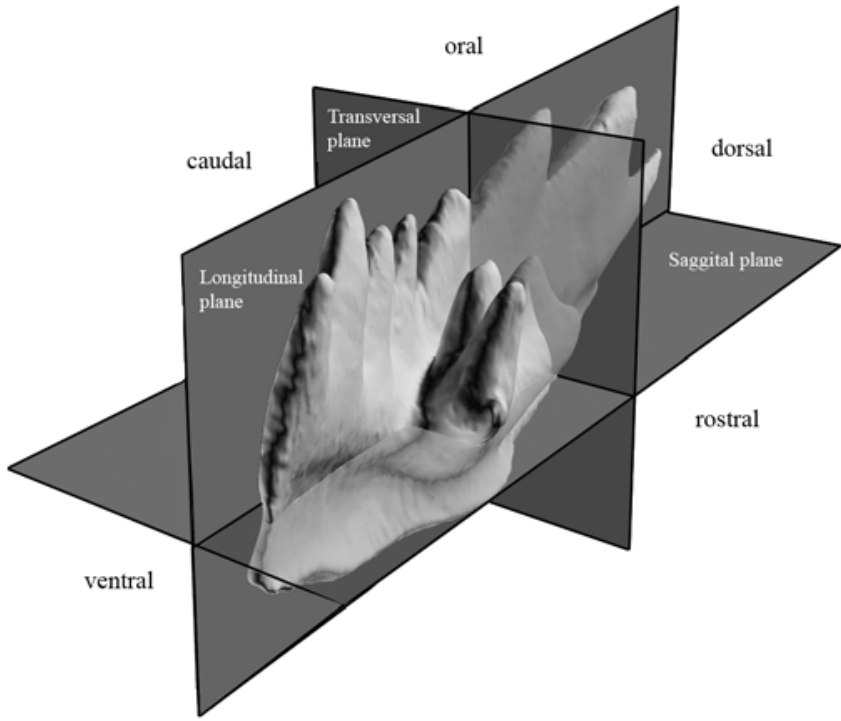

Figure 2. Schematic diagram of a $\mathrm{P}_{1}$ element of Pseudofurnishius murcianus illustrating histological planes of section (transversal, longitudinal and saggital planes), together with the different anatomical terms. Not to scale.

\section{HISTOLOGICAL DESCRIPTION}

The histological study of $P$. murcianus $\mathrm{P}_{1}$ elements has allowed us to discern a number of different microstructural organizations within the crown tissue, arrangement summarised in Figure 3a. Although the preservation of 


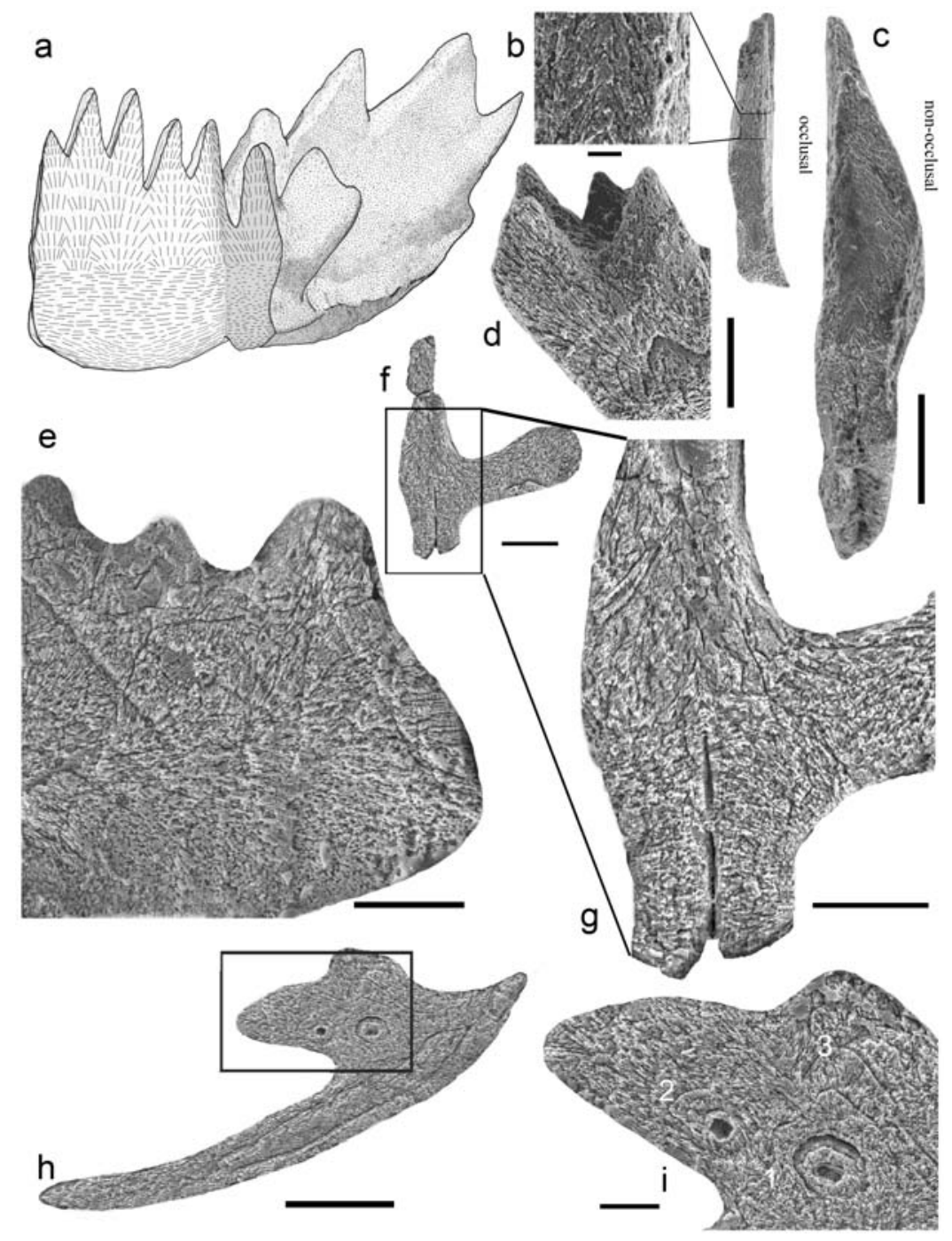

Figure 3. Thin sections and artificial fractures of $\mathrm{P}_{1}$ of $P$. murcianus from the Bugarra Section, sample Bu-1-26d (Iberian Range, Ladinian) showing the inner microstructure after etching 5-6 min with orthophosphoric acid $0.5 \%$. a) Diagrammatic summary of microstructure variation within the crown tissue in longitudinal and transversal planes. b) Transversal ground section of a Pseudofurnishius' dorsal free blade composed by crystallites arranged in layers sub-parallels to the outer surface (MGUV 21.325). c) Artificial fracture in the transversal plane of a $\mathrm{P}_{1}$ element showing a greater development of subparallel crystallites of the non-occlusal side (MGUV 21.326). d) Transversal artificial fracture showing the crystallites arranged approximately perpendicular to the outer surface of the platform denticles (MGUV 21.327). e) Longitudinal ground section of the specimen MGUV 21.324 showing the different arrangement of the crystallites between the upper and lower part of the element. f, g) Transversal ground section showing the crystallites arranged not perpendicular to the outer surface in the platform area (MGUV 21.322). h, i) Saggital ground section showing the successive addition of denticles during the ontogenetic development (MGUV 21.323): (h) general view; (i) detail of the platform showing: 1, Initial denticle and 2 and 3 stage denticles. Scale bar for c, d, g, h= $50 \mu \mathrm{m} ; \mathrm{b}, \mathrm{e}, \mathrm{f}=30 \mu \mathrm{m} ; \mathrm{i}=20 \mu \mathrm{m} ; \mathrm{b}=8$ $\mu \mathrm{m}$ and a not to scale. the specimens is not good, our interpretations are based on the examination of more than 20 specimens, allowing us to elucidate the general arrangement of the crystallites in the crown tissue. In all the specimens, the crown is make by singles prismatic crystallites of hydroxyapatite arranged in layers, with different orientations in different regions of the platform.

In longitudinal (dorsal-ventral) section is clearly discernible that the lower one-third of the element is composed of crystallites arranged subparallel to the basal cavity surface while the oral "region" of the element is characterised by crystallites arranged approximately perpendicular to the outer surface, with a fan-like distribution (dorsal to ventral) within each denticle (Fig. 3e). On the other hand, in transverse section, the occlusal and non-occlusal surfaces of the denticles of the dorsal and ventral blades are characterised by layers of crystallites arranged subparallel or oblique to the outer surface on both sides of the blade (Figs 3b-c, g). In addition, the non- occlusal side of the element exhibits a greater development of the lamella tissue than the occlusal side (Fig. 3c). In transversal or cross section the denticles' platform seem to follow a similar crystallite distribution that those showed in the denticles of the blade, with crystallites arranged perpendicular to the outer surface in a fan-like distribution (Figs 3d, h-i). On the other hand, the crystallites look to be arranged sub-parallel to the oral platform surface (Fig. $3 \mathrm{~g}$ ). In saggital sections, the rostral platform also shows evidences of the accretion order of the different dentciles, with the primary denticle growing from the blade, and posteriorly more denticles added dorsally and ventrally respectively, by adding single layers of prismatic crystallites (Figs 3h-i). 


\section{DISCUSSION}

$\mathrm{P}_{1}$ element function of Pseudofurnishius murcianus has been recently described in detail (Martínez-Pérez et al., 2014b). These authors suggest that the opposed elements occluded approximately orthogonal to their attachment surface, separating the elements during the cycle to allow the entry of food particles (Fig. 4). In this cycle, the dorsoventral blade aligned the approaching elements and their occlusion is refined by the interdigitation of denticles in the processes that comprise the rostral platform (MartínezPérez et al., 2014b). This occlusal cycle was supported by independent analyses of wear and denticle sharpness, demonstrating that the $\mathrm{P}_{1}$ elements of $P$. murcianus could perform a slicing function similar to Wurmiella excavata (Jones et al., 2012) or Vogelgnathus campbelli (Purnell \& von Bitter, 1992).

Our histological data is in agreement with this hypothesis, showing that the hypermineralised crown tissue is differentiated in several microstructural types in order to enhance their inner resistance due to its tooth-like function. The most evident microstructural feature of the crown is the presence of crystallite aligned in different direction between the oral and aboral parts of the blade. This arrangement reduces the homogeneity of the tissue, and thereby confers enhanced resistance to crack propagation (Rensberger, 1995). This crystallite distribution, with important differences between the oral and aboral part of the blade, together with the wider development of the nonocclusal side of the blade, could be also related with the increasing of resistance to the torsion effect generated by the scissor-like movement between the two elements. On the other hand, the denticles are composed of prismatic crystallites aligned approximately perpendicular to the external surface in a fan-like arrangement (Fig. 3e). This particular distribution is interpreted as a mechanical adaptation to tooth function, with crystallites optimal arranged to be more resistant to wear (wear that has been clearly documented for this taxon in Martínez-Pérez et al., 2014b). The crystallite arrangement in the platform denticles seems to follow a similar distribution to those showed by the blade denticles, with the crystallites arranged in a fan-like structure more or less perpendicular to the oral surface (Fig. 3d). Interestingly, the crystallites in the surface of the platform are clearly not perpendicular to the oral surface (Fig. 3g). This features could imply that although the denticles can be more resistant to wear, the arrangement of the crystallites on the oral surface of the platform seem not optimal aligned to resist loads, indicating that the platform is not "well adapted" to this task. This idea is supported by the occlusal model developed by Martínez-Pérez et al. (2014b) after the analysis of several $\mathrm{P}_{1}$ clusters (elements fused diagenetically) of P. murcianus from Slovenia. This model shows how both platforms clearly interlocked (Martínez-Pérez et al., 2014b), with the caudal side of right element overlapping the rostral side of the left one (Fig. 4). However, the complex and irregular distribution of the denticles in the platform (i.e., Figs 1b-c) should make difficult an interlocking occlusion comparable to other pectiniform conodonts (Donoghue \& Purnell, 1999a; Martínez-Pérez et al., 2014a). This slicing function is supported by wear evidences (Martínez-Pérez et al., 2014b), and by the characteristic asymmetrical blades, where the non-occlusal side of the element exhibits thicker lamellae than the occlusal side (Fig. 3c). This asymmetry is related with the blades shearing one to another during its occlusal cycle and therefore requiring a planar surface to a more accurate process (Purnell \& von Bitter 1992; Purnell 1995). Therefore, these evidences suggest that the platform wasn't involved directly in the food process, but helping during the occlusion movement, being the blades the morphological elements that actively processed the food.

In agreement with this view, the microstructure of the occlusal and non-occlusal sides of the dorsal and ventral blades supports again this idea. P. murcianus shows a similar microstructre described in other conodonts as Wurmiella, Palmatolepis, Idiognathodus or Gnathodus (Donoghue, 2001; Martínez-Pérez et al., 2014a), basically composed by crystallites arranged in layers sub-parallels to the outer surface (Fig. 3b). This alignment of the subsurface crystallites perpendicular to the shearing forces is at first sight counterintuitive because with this orientation the crystallites are less resistant to wear that those arranged parallel to the applied force (Rensberger \& von Koenigswald, 1980). But Donoghue (2001) suggests that this may be an "extreme" adaptation to the functional development of an occlusal surface with sharper cutting edges, avoiding the lost of important parts of the element caused by the crack propagation along the crystal boundaries. These combinations of different microstructural types described in the $\mathrm{P}_{1}$ elements of $P$. murcianus have been already described in the taxa cited before, and seem to be common to those conodont species in which $\mathrm{P}_{1}$ develop a blade-like morphology (Donoghue, 2001), strongly supporting the general hypothesis that changes in the crown microstructure are functional adaptations to the tooth-like function that the conodont elements performed (see as well Martínez-Pérez et al., 2014a).

\section{CONCLUSIONS}

The histological study of $\mathrm{P}_{1}$ elements of $P$. murcianus, although limited by the sample preservation, has allowed us to elucidate the inner microstructure of their platform elements, where different microstructural types can be recognized. These data can be interpreted as mechanical adaptations to slicing function, with crystallites optimally arranged to be more resistant to wear, or distributed in 


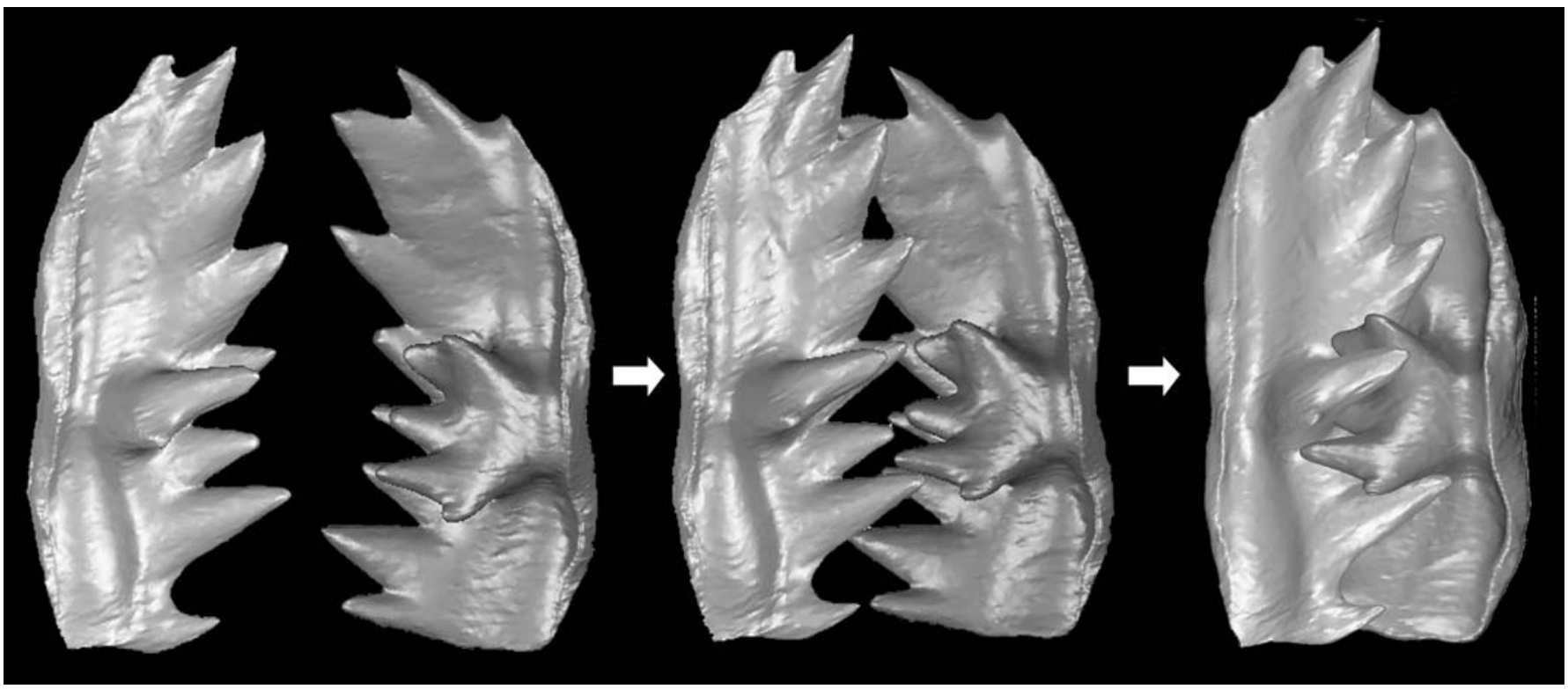

Figure 4. Pseudofurnishius murcianus $\mathrm{P}_{1}$ digital reconstruction of the occlusal cycle in rostral view, with the opposed elements approaching approximately orthogonal to their attachment surface. Modified from Martínez-Pérez et al. (2014b).

different directions to prevent crack propagation. This combination of microstructural types seems to be common to those conodonts species that develops a blade-like morphology, supporting again the mechanical function of these microstructures types (Donoghue, 2001; MartínezPérez et al., 2014a).

On the other hand, the "non-adaptive" arrangement of the crystallites in the outer surface of the platform, together with the particular distribution of the denticles in this area (with a irregular pattern of distribution specially in the more developed specimens), that makes difficult a complete occlusion of the platform, would suggest that the platform could develop more an alignment function to help during the occlusion cycle, rather to process the food actively. Our results are in agreement with the occlusal model proposed by Martínez-Pérez et al. (2014b), based on the digital and physical reconstruction of the cycle and supported by microwear data, strongly supporting the tooth like function of the $\mathrm{P}_{1}$ elements of Pseudofurnishius murcianus.

\section{ACKNOWLEDGEMENTS}

The work was funded by Marie Curie FP7-People IEF 2011-299681 to C.M.P. We thank to Dr. Mark Purnell (University of Leicester) and an anonymous reviewer for their comments and suggestions that have improved considerably the final manuscript. We aslo thank Victor Selles de Lucas (http://www.paleomatics.com) for the draws of the Figures 1 and 2. This work was supported by the Spanish Research Project CGL2014-52662-P.

\section{REFERENCES}

Bandel, K. \& Waksmundzki, B. 1985. Triassic conodonts from Jordan. Acta Geologica Polonica, 35, 3-4, $289-304$.

Blieck, A., Turner, S., Burrow C.J., Schultze, H.P., Rexroad, C.B., Bultynck, P. \& Nowlan, G.S. 2010. Fossils, histology, and phylogeny: Why conodonts are not vertebrates. Episodes, 33, 4, 234-241.

Clemens, W.A., 1997. Characterization of enamel microstructure and application of the origins of prismatic structures in systematic analyses. In: Tooth enamel microstructure (eds. v. Koenigswald, W. \& Sander, P.M.). A.A. Balkema, Rotterdam, 85-112.

Donoghue, P.C.J. 1998. Growth and patterning in the conodont skeleton. Philosophical Transactions of the Royal Society of London, Series B, 353, 633-666.

Donoghue, P.C.J. 2001. Microstuctural variation in conodont enamel is a functional adaptation. Proceedings of the Royal Society of London, Series B, 268, 1691-1698.

Donoghue, P.C.J. \& Aldridge, R.J. 2001. Origin of a mineralised skeleton. In: Major events in early vertebrate evolution: palaeontology, phylogeny, genetics and development (ed. Ahlberg, P.E.). Taylor \& Francis, London, 85-105.

Donoghue, P.C.J, \& Purnell, M.A. 1999a. Mammal-like occlusion in conodonts: Paleobiology, 25, 58-74.

Donoghue, P.C.J. \& Purnell, M.A. 1999b. Growth, function, and the conodont fossil record. Geology, 27, 251-254.

Donoghue, P.C.J, Forey, P.L.M. \& Aldridge, R.J. 2000. Conodont affinity and chordate phylogeny. Biological Reviews, 75, 91-251.

Gillis, J.A. \& Donoghue, P.C.J. 2007. The homology and phylogeny of chondrichthyan tooth enameloid. Journal of Morphology, 268, 33-49. 
Heckert, A.B. \& Miller-Camp, J.A. 2013. Tooth enamel microstructure of Revueltosaurus and Krzyzanowskisaurus (Reptilia:Archosauria) from the Upper Triassic Chinle Group, USA: Implications for function, growth, and phylogeny. Palaeontologia Electronica, 16(1), 1A, 23 p.

Ishida, K. \& Hirsch, F. 2011. The Triassic conodonts of the NW Malayan Kodiang Limestone revisited: Taxonomy and paleogeographic significance. Gondwana Research, 19, 22-36.

Jones, D., Evans, A.R., Siu, K.K.W., Rayfield, E.J. \& Donoghue, P.C.J. 2012. The sharpest tools in the box? Quantitative analysis of conodont element functional morphology. Proceedings of the Royal Society B., 279, 2849-2854.

Koenigswald, von W. 1988. Enamel modification in enlarged front teeth among mammals and the various possible reinforcements of the enamel. In: Teeth Revisited (eds. Russell, D.E. \& Sigogneau-Russell, D.). Mémoires du muséum national d'histoire naturelle, Paris, série C 53, 148-165.

López-Gómez, J., Arche, A. Calvet, F. \& Goy, A. 1998. Epicontinental marine carbonate sediments of the Middle and Upper Triassic in the westernmost part of the Tethys Sea, Iberian Peninsula. Zentralblatt für Geologie und Paläontologie, 2, 1033-1084.

Martínez-Pérez, C., Donoghue, P.C.J., Rayfield, E.J. \& Purnell, M.A. 2014a. Finite elements, occlusion and wear analyses indicate that conodont microstructure is adapted to dental function. Palaeontology, 57, 1059-1066.

Martínez-Pérez, C., Plasencia, P., Jones, D.O., KolarJurkovšek, T., Sha, J., Botella, H. Donoghue, P.C.J. 2014 b. There is no general model for occlusal kinematics in conodonts. Lethaia, 47, 547-555.

Murdock, D.J., Sansom, I.J., Donoghue, P.C.J. 2013a. Cutting the first 'teeth' - a new approach to functional analysis of conodont elements. Proceedings of the Royal Society B: Biological Sciences, 280, 20131524.

Murdock, D.J.E., Dong X.-P., Repetski, J.E., Marone, F., Stampanoni, M. \& Donoghue, P.C.J. 2013b. The origin of conodonts and of vertebrate mineralized skeletons. Nature, 502, 546-549.

Nicoll, R.S. 1987. Form and function of the Pa element in the conodont animal. In: Palaeobiology of conodonts (ed. Aldridge, R.J.). Ellis Horwood, Chichester, United Kingdom, 77-90.

Plasencia, P. 2009. Bioestratigrafía y paleobiología de conodontos del Triásico Medio del Sector Oriental de la Península Ibérica. Servei de Publicacions de la Universitat de Valencia.
Plasencia, P., Hirsch, F. \& Márquez-Aliaga, A. 2007. Sephardiellinae, a new Middle Triassic conodont subfamily. Journal of Iberian Geology, 33, 163-172.

Plasencia, P., Hirsch, F. \& Márquez-Aliaga, A. 2010. On the ontogeny and orientation of the Triassic Conodont $\mathrm{P}_{1}$ element in Pseudofurnishius murcianus van den Boogaard, 1966. Geobios, 43, 547-553.

Plasencia, P., Hirsch, F., Sha, J. \& Márquez-Aliaga, A. in press. Taxonomy and evolution of the Triassic conodont Pseudofurnishius. Acta Palaeontologica Polonica, doi: 10.4202/app.2012.0048

Purnell, M.A. 1994. Skeletal ontogeny and feeding mechanisms in conodonts. Lethaia, 27, 129-138.

Purnell, M.A. 1995. Microwear on conodont elements and macrophagy in the first vertebrates. Nature, 374, 798-800.

Purnell, M.A. \& von Bitter, P.H. 1992. Blade-shaped conodont elements functioned as cutting teeth. Nature, 359, 629-630.

Ramovs, A. 1977. Skelettapparat von Pseudofurnishius murcianus (Conodontophorida) in der Mitteltrias Sloweniens (NW Jugoslawien). Neues Jahrbuch für Geologie und Paläeontologie. Abhandlungen, 153, 361-399.

Ramovs, A. 1978. Mitleltriassische Conodonten-clusters in Slowein, NW Jugoslavien. Paläontologische Zeitschrift, 52, 129-137.

Rensberger, J.M. 1992. Relationship of chewing stress and enamel microstructure in rhinocerotoid cheek teeth. In: Structure, Function and Evolution of teeth (eds. Smith, P. \& Tchernov, E.). Freund Publishing House, London, 163-183.

Rensberger, J.M. 1993. Adaptation of enamel microstructure to differences in stress intensity in the Eocene perissodactyl Hyracotherium. In: Structure, Formation and Evolution of fossil hard tissues (eds. Mutvie, H. \& Sahni, A.). Tokai University Press. Tokio, 131-145.

Rensberger, J.M. 1995. Determination of stresses in mammalian dental enamel and their relevance to the interpretation of feeding behaviors in extinct taxa. In: Functional Morphology in Vertebrate Paleontology (ed. Thomason, J.). Cambridge University Press, Cambridge, 151-172.

Rensberger, J.M. 1997. Mechanical adaptations in enamel. In: Tooth enamel microstructure (eds. v. Koenigswald, W. \& Sander, P.M.). A.A. Balkema, Rotterdam, 237-257.

Rensberger, J.M. \& von Koenigswald, W. 1980. Functional and phylogenetic interpretation of enamel microstructure in rhinoceroses. Paleobiology, 6, 477-495.

Turner, S., Burrow, C.J., Schultze, H.P., Blieck, A., Reif, W.E., Rexroad, C.B., Bultynck, P. \& Nowlan, G.S. 2010. False teeth: conodont-vertebrate phylogenetic relationships revisited: Geodiversitas, 32(4), 545-594. 
